HELMINTHOLOGIA, 51, 3: 190 - 197, 2014

\title{
First finding of Trichinella pseudospiralis in two Tawny Owls (Strix aluco) from Sweden
}

\author{
Z. HURNÍKOVÁ ${ }^{1,2}$, G. HRČKOVÁ ${ }^{2}$, E. ÅGREN ${ }^{3}$, P. KOMOROVÁ ${ }^{1}$, J. FORSMAN $^{1}$, B. CHOVANCOVÁ ${ }^{4}$, \\ L. MOLNÁR ${ }^{1}$, V. LETKOVÁ ${ }^{1}$
}

\begin{abstract}
${ }^{1}$ University of Veterinary Medicine and Pharmacy, Komenského 73, 04181 Košice, Slovakia,
E-mail: hurnikova@uvlf.sk; ${ }^{2}$ Institute of Parasitology, Slovak Academy of Sciences, Hlinkova 3, 04001 Košice, Slovakia; ${ }^{3}$ Department of Pathology and Wildlife Diseases, National Veterinary Institute, SE-751 89 Uppsala, Sweden; ${ }^{4}$ Research Station and Museum of the Tatra National Park, 05960 Tatranská Lomnica, Slovakia
\end{abstract}

\begin{abstract}
Summary
The worldwide distribution of Trichinella pseudospiralis, the first discovered non-encapsulated Trichinella species infecting both mammals and avian hosts, has been suggested to be attributed to bird migration. At present, the knowledge on the role of carnivorous avian species as a reservoir hosts in Europe is still limited. Thus, the aim of this research was to screen for $T$. pseudospiralis in raptorial, carrion-feeding, and scavenging birds in Sweden and Slovakia, where the parasite has been previously documented in wildlife. In total, 212 pectoral muscle samples of carnivorous birds from Slovakia $(n=153)$ and Sweden $(\mathrm{n}=59)$ were examined for the presence of Trichinella larvae using standard artificial digestion method. Out of 12 Accipitridae species, 4 Falconidae species, 2 Strigidae species, 1 Tytonidae species, and 4 Corvidae species examined within our study, muscle larvae were found in two non-migratory tawny owls (Strix aluco) from one geographical region of Sweden. Histological and molecular methods confirmed the presence of T. pseudospiralis. This is the first report of this parasite in an avian species in Sweden and the second report in European birds.
\end{abstract}

Keywords: Trichinella pseudospiralis; epidemiology; carnivorous birds; birds of prey; tawny owl; Strix aluco; Sweden; Slovakia

\section{Introduction}

Nematode parasites of the genus Trichinella are the agents of worldwide disease in both sylvatic and domestic epidemiological cycles and also cause an important foodborne zoonosis. The parasite has low host specificity and is able to infect a broad spectrum of mammalian hosts. Trichinella pseudospiralis is the first discovered non-encapsulated Trichinella species (Garkavi, 1972), unique among other species by infectivity not only for mammals, but also for avian species. Trichinella pseudospiralis is known to have 190 a cosmopolitan distribution and world-wide, 63 isolates of the species have been detected in mammals and birds to date (Pozio \& Zarlenga, 2013). In Europe, so far two cases of T. pseudospiralis infection have been documented in sedentary night-birds of prey in central Italy - in a tawny owl (Strix aluco) and a little owl (Athene noctua) by Pozio et al. (1999). It has been suggested that carnivorous birds might play a role in maintaining the parasite in the sylvatic cycle and are probably related to the spread of the parasite (Pozio \& Murrell, 2006). Pozio et al. (2004) suggested that the few cases of $T$. pseudospiralis that have been recorded recently in the European region have originated from migratory birds of temperate regions such as Scandinavia.

To support this hypothesis, monitoring of Trichinella spp. in birds from other European countries is required. There is lack of data on the prevalence of $T$. pseudospiralis in raptorial, carrion-feeding, and scavenging birds in Sweden and Slovakia, where the parasite has been documented in wildlife (Pozio et al., 2004; Hurníková \& Dubinský, 2009). In Sweden, T. pseudospiralis has been detected in three wild boars from mid-Sweden (Stockholm County) and in a lynx from northern Sweden (Jämtlands County) in the years $1985-2003$. This suggests that $T$. pseudospiralis is present sporadically and multifocally in Sweden (Pozio et al., 2004) and also throughout the Scandinavian Peninsula (Oivanen et al. 2002; Oivanen \& Oksanen 2009; Airas et al., 2010). In Slovakia, the first focus of T. pseudospiralis was documented from a pig breeding farm in Eastern Slovakia in 2004 (Hurníková et al., 2005) and was later found in co-infection with T. britovi in a wild boar and in red foxes from the same region suggesting the establishment of wildlife circulation of the parasite (Hurníková \& Dubinský, 2009).

The aims of our work were to study the presence of $T$. pseudospiralis in carnivorous birds from Slovakia and Sweden using parasitological methods as well as molecular and histological identification of nematode isolates, and to 
determine the possible role of raptorial and carrion-feeding birds in the epidemiology of T. pseudospiralis.

\section{Material and methods}

\section{Parasitological investigation}

Pectoral muscle samples from a total 212 carnivorous birds, belonging to 5 families - Accipitridae (12 species), Falconidae (4 species), Strigidae (2 species), Tytonidae (1 species), and Corvidae (4 species) as shown in table 1 were examined within our study. Investigated samples were collected during 2007 - 2013 from carcasses found by workers of the Research Station and Museum of the Tatra National Park, or from birds that died in raptor rescue centers and bird clinics in Slovakia $(n=153)$. From Sweden, samples were donated from the National Veterinary Institute's (SVA) biobank for the purpose of our study $(n=59)$. These samples had previously been cryopreserved and stored in SVA's biobank after necropsies within the national wildlife disease surveillance program. Samples were taken from 1994 - 2011 and in 2012 they were sent to the University of Veterinary Medicine and Pharmacy in Košice for investigation. Individual pectoral muscle samples $(5-20 \mathrm{~g})$ were examined for the presence of Trichinella larvae by artificial digestion according to standard methods (Gamble et al., 2000) within 2012 and 2013. The number of larvae per gram of muscle tissue (lpg) was determined according to Kapel and Gamble (2000). Larvae from infected birds were preserved in $70 \%$ ethanol until molecular identification.

\section{Isolation of DNA and polymerase chain reactions}

Firstly, DNA was isolated from single larvae using $10 \mu \mathrm{l}$ of extraction mixture according to the protocol described by Pozio and La Rosa (2003). Samples of isolated larvae were incubated overnight at $54{ }^{\circ} \mathrm{C}$ following an inactivation step at $90{ }^{\circ} \mathrm{C}$ for $10 \mathrm{~min}$. To identify Trichinella species, the universal primer set (forward: 5'-GTTCCATGT GAACAGCAGT-3') and (reverse: 5'-CGAAAACATACG ACAACTGC-3') amplifying 1sr DNA-derived expansion segment $\mathrm{V}$ (ESV) sequences described previously by Zarlenga and Dame (1992) was used in PCR reactions. The PCR mixture (total volume of $25 \mu \mathrm{l}$ ) consisted of $2.5 \mu \mathrm{l}$ of 10x PCR buffer, $1 \mu \mathrm{l} 10 \mathrm{mM} \mathrm{MgCl} 2,1 \mu \mathrm{l}$ of $10 \mathrm{mM}$ dNTPs mix, $2 \mu \mathrm{l}$ of each $10 \mathrm{mM}$ primers, $3 \mu \mathrm{l}$ of isolated genomic DNA and $1 \mathrm{U}$ of Go Taq polymerase (Promega, USA). Reactions were carried out in BioRad C1000 Thermal Cycler and after initial denaturation at $95{ }^{\circ} \mathrm{C}$ for $4 \mathrm{~min}$, the following cycling conditions in total 40 cycles were: $95^{\circ} \mathrm{C}$ for $30 \mathrm{sec}, 55^{\circ} \mathrm{C}$ for $30 \mathrm{sec}$ and $72{ }^{\circ} \mathrm{C}$ for 1 min. Total genomic DNA was also isolated from $T$. pseudospiralis (code ISS13), T. spiralis (ISS004) and $T$. britovi (ISS1088) reference strains, maintained in laboratory mice. In addition, samples of DNA from four geographically related $T$. pseudospiralis isolates previously used in the study of Wu et al. (2007) were kindly provided by Dr. Vilam Šnábel. Of these, three isolates were stated as reference samples characterized by code number and lo- cality, namely ISS1348 (Sweden), ISS1432 (Slovakia), ISS141 (Australia-Tasmania) and one non-reference isolate from Finland. Amplification of corresponding ESV gene sequence was performed under the same reaction conditions and amplicons were electrophoresed on $1.5 \%$ agarose gel and stained with ethidium bromide.

Amplification of a $419 \mathrm{bp}$ region of the mitochondrial cytochrome c-oxidase subunit COI gene was performed on total DNA isolated from a higher number of muscle larvae with DNA Tissue isolation Kit (Machery Nagel, Germany) due to the lack of signal in PCR reactions on DNA from 3 larvae.

Trichinella spp. specific primers L6625 (5'-TTYTGRTTY TTYGGNCAYCC-3') and H7005 (5'-ACNACRTARTAN GTRTCRTG-3') originally reported by Hafner et al. (1994) were used in PCR reactions and amplification was performed under the reaction conditions described by Nagano et al. (1999).

\section{RFLP analysis of COI gene}

After electrophoresis, an approximately 419 bp band, previously characterized by a high variability among $T$. pseudospiralis isolates (La Rosa et al. 2001; Wu et al. 2007) was subjected to RFLP analysis (restriction fragment length polymorphism) with restriction endonuclease RsaI Fast digest (Fermentas) according to the manufacturer's instructions. PCR products for above mentioned isolates were purified using NucleoSpin Gel and PCR Clean-up Kit (Machery-Nagel, Germany). Digested products were electrophoresed in $4 \%$ agarose gel and visualized after addition of ethidium bromide.

\section{Histological examination}

Muscle tissue from two positive tawny owls, stored in $10 \%$ formaline, was delivered from SVA for the histological examination. After an intensive washing in tap water, tissue blocks were processed by standard procedures and embedded in paraffin. Tissue sections $(5-8 \mu \mathrm{m}$ thick $)$ were stained with Mayer's haematoxylin/eosin, dehydrated, cleared in the Histochoice clearing solution and mounted in Histochoice mounting fluid (Amresco, USA).

\section{Results}

\section{Parasitological investigation}

Out of 212 carnivorous bird samples recovered in Slovakia and Sweden (Table 1), Trichinella pseudospiralis larvae were found in two tawny owls (Strix aluco) from Sweden (Fig. 1). In tawny owl V1997-0431 from Stockholm County, the intensity of infection was $0.7 \mathrm{lpg}$. Tawny owl V2011-0076 from Uppsala County was infected with $1.6 \mathrm{lpg}$. Out of the the total 59 samples originating from Sweden, 38 were from tawny owls. The prevalence of $T$. pseudospiralis in tawny owls from Sweden was $5.26 \%$. Trichinella pseudospiralis was not confirmed in any other avian species included in the study, neither from Slovakia nor from Sweden. 
Table 1. Raptorial and carrion-feeding birds examined for Trichinella pseudospiralis in Slovakia and Sweden

\begin{tabular}{|c|c|c|c|c|}
\hline \multirow[b]{2}{*}{ Family } & \multirow[b]{2}{*}{ Species } & \multirow[b]{2}{*}{$\begin{array}{c}\text { Migratory } \\
\text { status }\end{array}$} & \multicolumn{2}{|c|}{ No. of examined/positive } \\
\hline & & & Slovakia & Sweden \\
\hline \multirow[t]{12}{*}{ Accipitridae } & Montagu's harrier (Cicrus pygagrus) & FM & $2 / 0$ & - \\
\hline & Western marsh-harrier (Circus aeruginosus) * & $\mathrm{P}$ & $4 / 0$ & - \\
\hline & Northern harrier (Circus cyaneus) & $\mathrm{P}$ & $1 / 0$ & - \\
\hline & Eurasian sparrowhawk (Accipiter nisus) & $\mathrm{P}$ & $8 / 0$ & - \\
\hline & Goshawk (Accipitergentilis) & $\mathrm{P}$ & $4 / 0$ & - \\
\hline & Golden eagle (Aquila chrisaetos) & $\mathrm{R}$ & $1 / 0$ & - \\
\hline & Imperial eagle (Aquila heliaca) & $\mathrm{P}$ & $1 / 0$ & - \\
\hline & Lesser spotted eagle (Aquila pomarina) & M & $2 / 0$ & - \\
\hline & Red kite (Milvus milvus) & $\mathrm{P}$ & $1 / 0$ & - \\
\hline & Common buzzard (Buteo buteo) & $\mathrm{M}$ & $41 / 0$ & $12 / 0$ \\
\hline & Rough-legged buzzard (Buteo lagopus) & FM & $1 / 0$ & $1 / 0$ \\
\hline & Long-legged buzzard (Buteo rufinus) & $\mathrm{R}$ & $1 / 0$ & - \\
\hline \multirow[t]{4}{*}{ Falconidae } & Common kestrel (Falco tinnunculus) & $\mathrm{P}$ & $19 / 0$ & - \\
\hline & Peregrine falcon (Falco peregrinus) & $\mathrm{R}$ & $5 / 0$ & $1 / 0$ \\
\hline & Merlin (Falco columbarius) & $\mathrm{P}$ & $1 / 0$ & $2 / 0$ \\
\hline & Saker falcon (Falco cherrug) & $\mathrm{P}$ & $1 / 0$ & - \\
\hline \multirow[t]{2}{*}{ Strigidae } & Tawny owl (Strix aluco) $\dagger$ & $\mathrm{R}$ & $6 / 0$ & $38 / 2(5.26 \%)$ \\
\hline & Long-eared owl (Asio otus) & $\mathrm{P}$ & $5 / 0$ & - \\
\hline Tytonidae & Barn owl (Tyto alba) & $\mathrm{P}$ & $1 / 0$ & - \\
\hline \multirow[t]{4}{*}{ Corvidae } & Carrion crow (Corvus corone) & $\mathrm{R}$ & $5 / 0$ & - \\
\hline & Common raven (Corvus corax) & $\mathrm{R}$ & $18 / 0$ & $5 / 0$ \\
\hline & Rook (Corvus frugilegus) $\ddagger$ & M & $14 / 0$ & - \\
\hline & Eurasian magpie (Pica pica) & $\mathrm{R}$ & $11 / 0$ & - \\
\hline
\end{tabular}

PCR analysis of ESV and COI gene

PCR amplification of expansion segment five (ESV) of the genomic large ribosomal subunit on DNA from larvae isolated from the tawny owls showed identical size with band for T. pseudospiralis reference strain (ISS1432) circulating in Slovakia (Fig. 2). Obtained isolates and the reference isolate were represented by a single dominant band migrating at approximately $300 \mathrm{bp}$, and were clearly distinguished from $T$. spiralis (170 bp fragment) and $T$. britovi (127 bp fragment). The size of the amplicons from PCR on three reference DNA isolates from the Palearctic region (approximately $300-310 \mathrm{bp}$ ) and one from the Australian region (approximately $330-340 \mathrm{bp}$ ), indicates that our isolates are genetically related to the Palearctic isolates (Fig. 3).

DNA from pooled larvae isolated from bird muscles was used in PCR with primers specific for mitochondrial COI gene loci for $T$. pseudospiralis, resulting in fragmented DNA banding profile. Consequently, the specific product of COI gene migrating at approximately $419 \mathrm{bp}$ was generated in PCR reactions with Trichinella spp. - specific primers, only. The band with the same size was amplified in PCR for all T. pseudospiralis reference isolates (Fig. 4.).

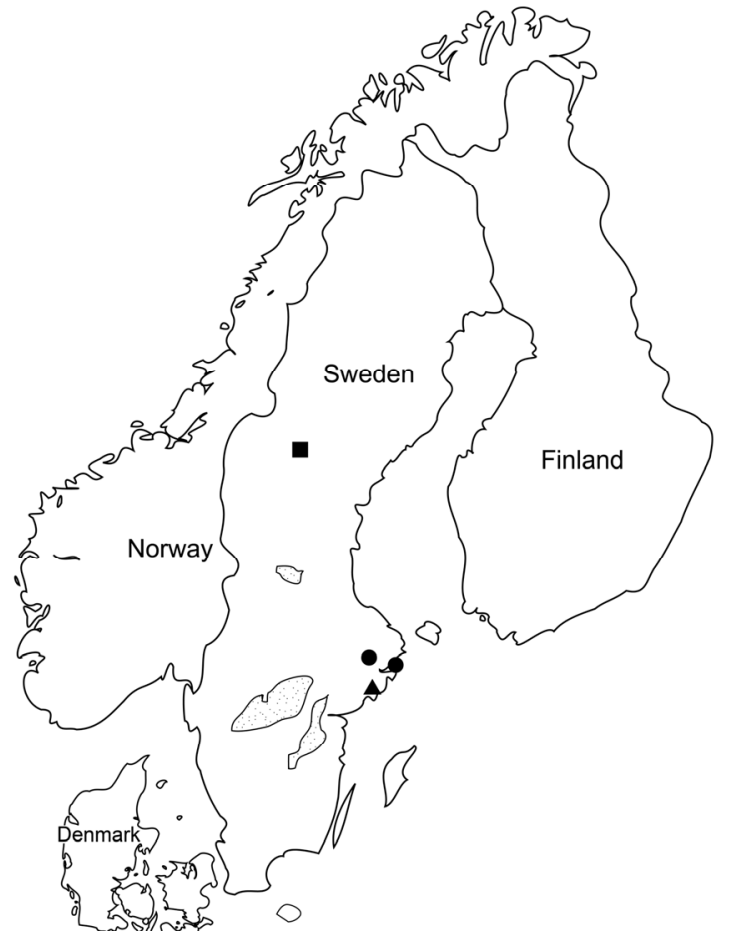

Fig. 1. Map of Sweden indicating findings of animals infected with T. pseudospiralis

Wild boars (Pozio et al., 2004); $\boldsymbol{\Delta}$ lynx (Pozio et al., 2004);

tawny owls (presented findings) 


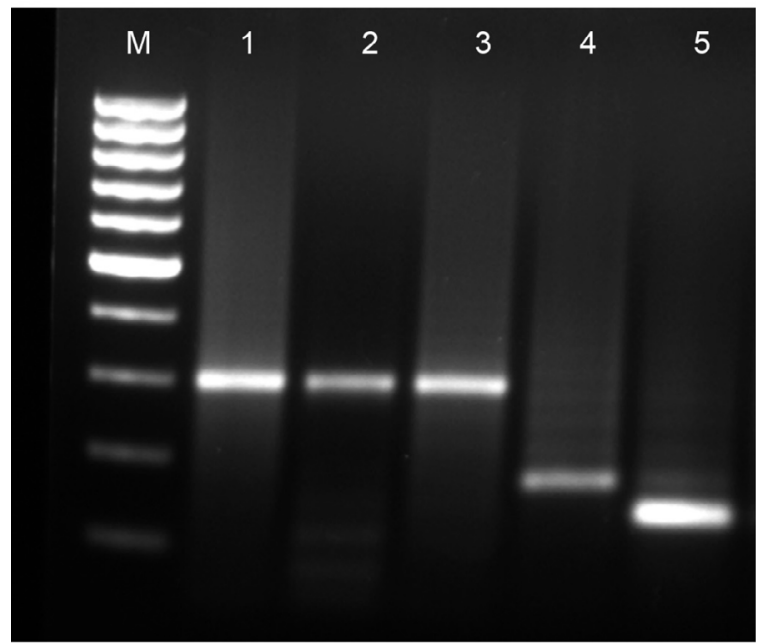

Fig. 2. Agarose gel separation of PCR products on DNA from 3 larvae amplified with primers specific for Trichinella spp. ESV gene.

Lanes: 1-2, Trichinella isolates from tawny owls, 3, T. pseudospiralis reference isolate (code ISS13); 4, T. spiralis (ISS004); 5, T. britovi

(ISS1088). 100 bp marker

Polymerase chain reaction-restriction fragment length polymorphism

RFLP analysis of COI gene fragment was used to further characterize the new T. pseudospiralis isolates. Specific profile obtained with restriction enzyme RsaI was identical among isolates from the Palearctic region, but was different among isolates from three different zoogeographic regions. The banding profile after RFLP analysis of COI gene of our isolates and reference isolates is shown on Fig. 5. All examined isolates from Palearctic region showed identical pattern formed of approximately $300 \mathrm{bp}$ and $100 \mathrm{bp}$ fragments and one isolate from Australian region produced RFLP profile of approximately 330 and $100 \mathrm{bp}$. Interestingly, the results obtained for our isolates showed bands migrating at approximately $280 \mathrm{bp}$ and $100 \mathrm{bp}$.

\section{Histological observations}

The muscle tissues obtained from the two positive tawny owls was moderately to markedly autolytic indicated by the loose of indistinct morphology of muscle fibers. After $\mathrm{H} \& \mathrm{E}$ staining of longitudinal and transversal sections, infection with nematode larvae was demonstrated as basophilic elongated cigar-shaped smooth organisms with a diameter of $20-25 \mu \mathrm{m}$ and filled with multiple nuclei in host muscle cells (Fig. 6a). The remnants of the larvae without the intact cuticule were seen inside infected muscle cells, which were transformed to nurse cells. These cells could be recognized as a weakly stained material without striated morphology. There was no indication of the presence of collagen capsules, typical for species such as Trichinella spiralis (Fig. 6b). Occasionally, cross sections of larvae were observed in the remnants of nurse cells (Fig. 6c) and nucleated larval-like material was observed between muscles (Fig. 6d).

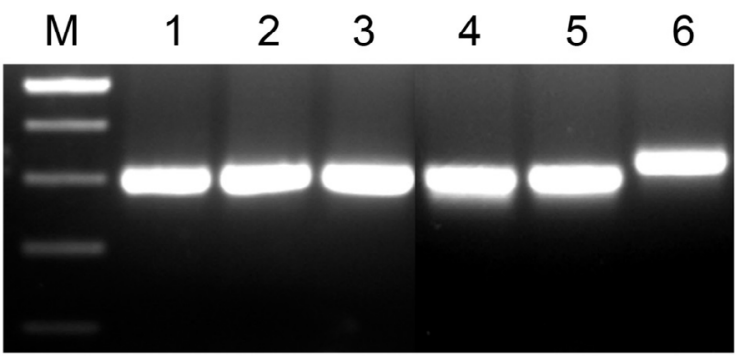

Fig. 3. Results from agarose gel electrophoresis of PCR products of ESV gene for Trichinella pseudospiralis genotypes representing Palearctic isolates. Lanes 1-3, Sweden (ISS1348), Finland, Slovakia (ISS1432); Lanes 4-5, new isolates from tawny owls; Lane 6, isolate (ISS141) from Tasmania. Reactions were performed on DNA isolated from multiple larvae. $100 \mathrm{bp}$ marker

\section{Discussion}

The increasing number of findings of $T$. pseudospiralis in mammals throughout Europe within the last decades (Nöckler et al., 2006; Pozio, 2009), may indicate that this parasite is prevalent in all potential natural hosts including birds. Since there are few studies on birds as hosts of Trichinella, there is not much data available to give an accurate picture of the role of carnivorous avian species as reservoir hosts in Europe. Furthermore, as raptorial species are protected by governmental bodies of most European countries, it is difficult to acquire an adequate number of samples for extensive surveillance studies. In the past and even presently, most studies on Trichinella in animals have primarily been focused on animals hunted for sport or meat, such as wild boars, while many other putative host species are unaccounted for (Pozio, 2005).

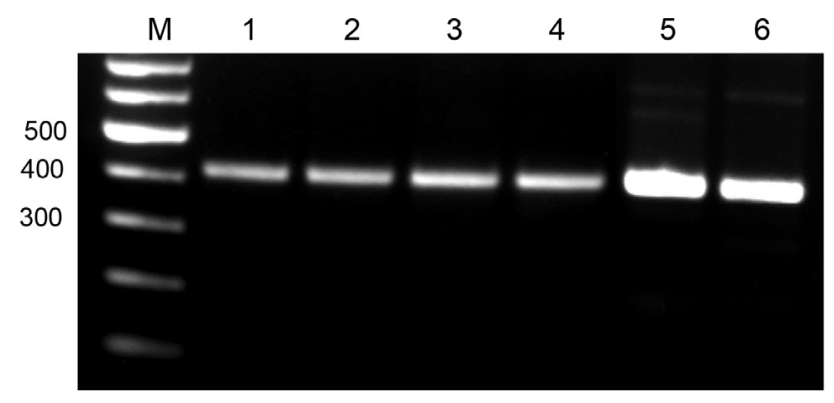

Fig. 4. Agarose gel showing a 419 bp products of COI gene generated in PCR on DNA for T. pseudospiralis isolates from Palearctic region (Lanes $1-3$ ), isolate from Australian region (Lane 4) and DNA of new isolates from tawny owls from Sweden. $100 \mathrm{bp}$ marker

Our study revealed two findings of Trichinella pseudospiralis in non-migratory tawny owls from one geographical region of Sweden. One tawny owl was sampled in Stockholm county in 1997 and the second in Uppsala county in 2011. These findings are the second report of cases of nocturnal birds of prey with T. pseudospiralis infection in Europe. The first finding of T. pseudospiralis in birds in Europe was documented in central Italy by Pozio et al. (1999), The only other similar finding of Trichinella-like larvae in birds within Europe was reported by Calero et al. in 1978 in a buzzard (Buteo buteo) in Spain, however, the larvae found 


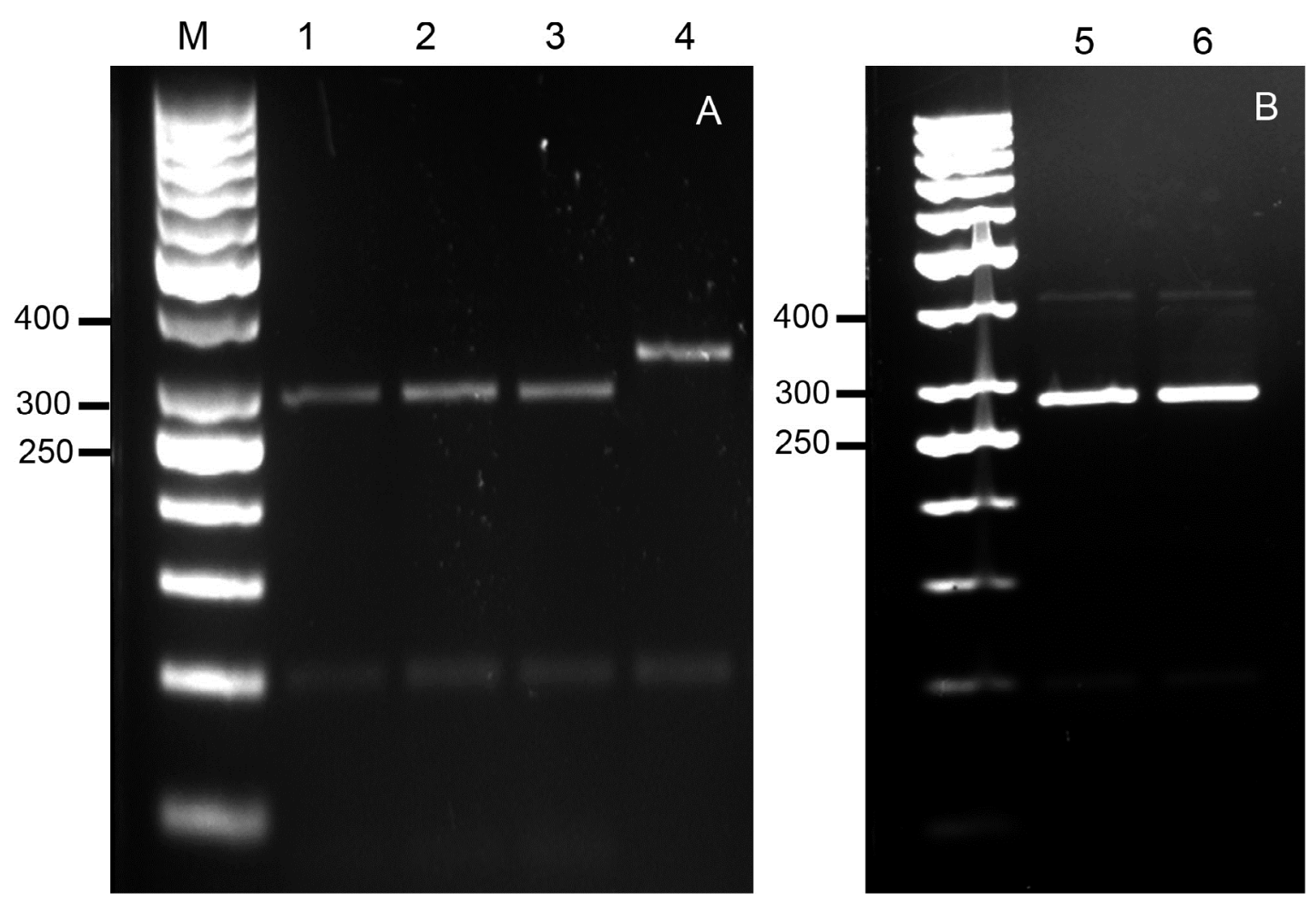

Fig. 5 a, b Banding profile of RFLP analysis of COI gene fragment obtained with RsaI restriction enzyme.

A, T. pseudospiralis reference isolates from Palearctic region (Lanes 1-3), isolate from Australian region (Lane 4).

$\mathrm{B}$, restriction enzyme profile for COI of the new isolates from Sweden. $50 \mathrm{bp}$ marker

in this specimen were not confirmed as T. pseudospiralis.

In our study, identification of the larvae isolated from muscles of two owls was performed by both molecular analysis and histological examination of formalin-fixed tissue. Firstly, in PCR on DNA from single intact larvae, Trichinella pseudospiralis was confirmed based on the length of the amplicon of lsr DNA-derived expansion segment V (ESV) using a primer set described by Zarlenga and Dame (1992). Zarlenga et al. (1999) showed that size variability within this region allows differentiation among zoogeographical isolates of $T$. pseudospiralis. The length of approximately $300 \mathrm{bp}$ indicates that our two Swedish isolates belong to the group of Palearctic genotypes and shows a genetic similarity with isolates previously obtained from Sweden, Finland, and Slovakia. The RFLP profile of COI gene for our isolates from Sweden differed moderately from banding profiles for other isolates from Palearctic region, which might indicate a higher level of polymorphism between our isolates and others from this zoogeographic region. Histological analysis of muscle sections revealed the presence of unencapsulated larvallike material localized in the remnants of nurse cells. The diameter and the morphology of larvae localized in experimentally infected mouse and bird's muscle were very similar (data not shown). These observations supported our molecular findings.

There was a very low prevalence of $T$. pseudospiralis found in the birds sampled in our study $(2 / 212,0.94 \%)$ as well as a low intensity of infection $(0.7 \mathrm{lpg}$ and $1.6 \mathrm{lpg}$, respectively). The only two birds in the study with Trichinella infection were non-migratory tawny owls from Sweden. This is one of two most abundant owl species in Sweden with 20,000 - 40,000 individuals ranging in woodlands and also rural habitats from the southern tip at $55^{\circ} \mathrm{N}$ to between $60-61^{\circ} \mathrm{N}$. The prey that tawny owls feed on in Sweden are primarily the small rodent species Arvicola terrestris and Microtus agrestis (Lundberg 1980), although their diet may also consist of earthworms, insects, birds, frogs, fish, lizards, molluscs, and crustaceans. Previous studies have observed parasitic nematode communities of owls and birds of prey in Europe and recognized that both intrinsic and extrinsic factors including diet, habitat, behavior, migration, sex, age, geographic range, and distribution may influence the richness of nematodes within this category of birds (Santoro et al., 2012).

Up to date, all confirmed cases of $T$. pseudospiralis in birds within Europe have only been from the family Strigidae. Nocturnal owls hunt during dusk and night-time when only a specific range of prey animals are present, whereas diurnal birds of prey have a wider range of prey species to feed on (Jaksic, 1982). Therefore, the findings of T. pseudospiralis in tawny owls in Sweden may be due to the population's selective feeding habits on a narrow range of rodent species (i.e. Arvicola terrestris and Microtus agrestis) that may be more commonly infected with the nematode. An extensive surveillance study on the prevalence of 

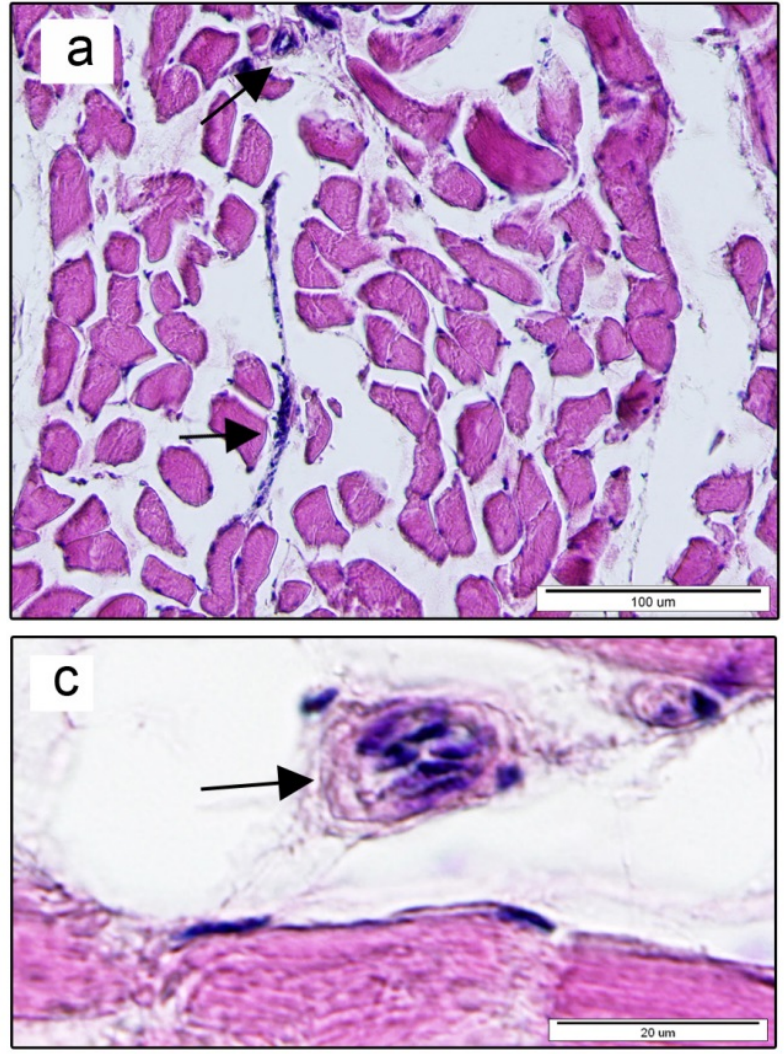
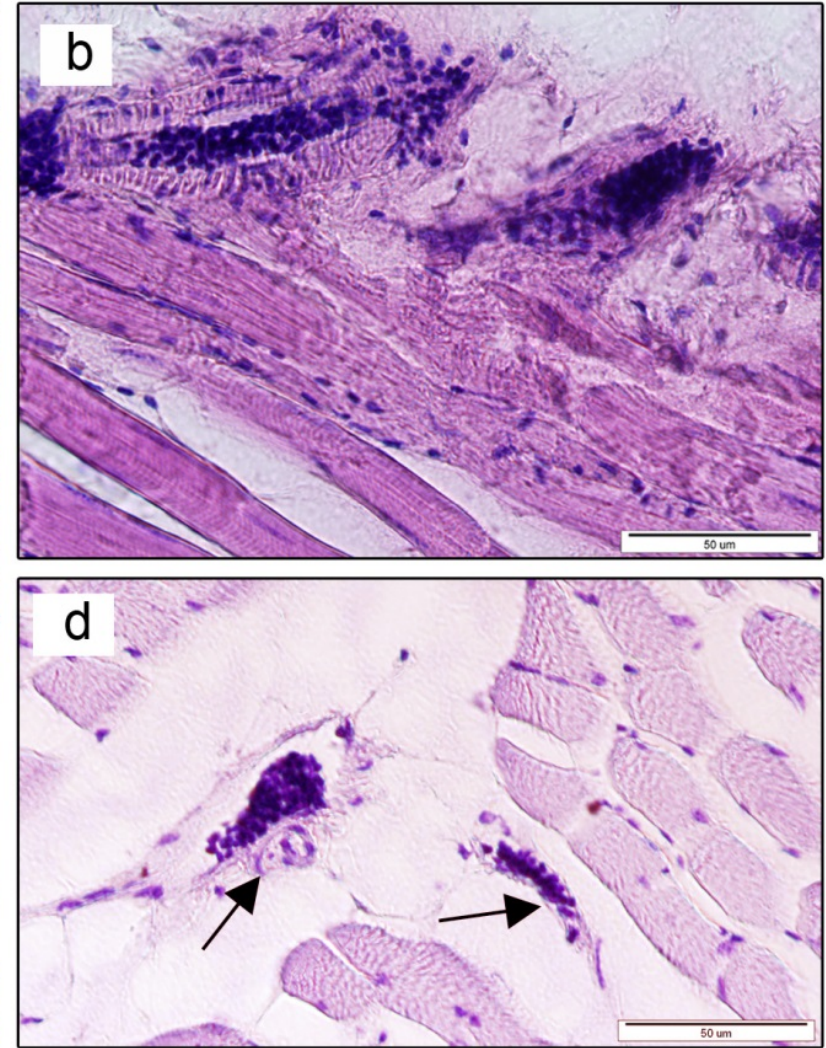

Fig. 6 a-d. Histological images of the muscles obtained from examined tawny owls suspected for T. pseudospiralis infection.

(a-d), Hematoxylin and eosin staining. Longitudinal (a) and transversal (b) sections of the larval-like material (arrows) localized inside remnants of the nurse cells seen as accumulation of dark blue staining; (c), cross- section of the partly damaged larva from infected bird's muscle;

(d) presence of larval-like material (arrows) localized between infected muscles

T. pseudospiralis in the rodent species that share a common habitat with Strix aluco is therefore relevant to our study and recommended in the future.

Another factor other than feeding habit that may influence the prevalence of $T$. pseudospiralis in owls is body size. Kinsella et al. (2001) suggest that body size is often related to other aspects of parasite transmission such as dietary range, rate of food intake, and population density. The fact that several confirmed cases of $T$. pseudospiralis in owls have been reported in different parts of the world including Europe, USA, and Tasmania suggest the possibility that this nematode may be an „owl specialist“" (Santoro et al., 2012) and has a higher host specificity for these species than diurnal raptors and other carnivorous birds.

Tawny owls are highly territorial, which would suggest that they are not directly involved in spreading of T. pseudospiralis parasite into new geographical regions. Our findings of this nematode in two tawny owls (5.26\% study prevalence in this species) indicate that this parasite is endemic to the area of Stockholm and Uppsala County. This is similar to the findings of Pozio et al. (2004) who detected the parasite in a lynx (Lynx lynx) and three wild boars (Sus scrofa) in Sweden. Trichinella pseudospiralis has also been detected in Finland (Oivanen et al. 2005; Airas et al., 2010) and Baltic countries (Malakauskas et al., 2007). Since several decades, various reports have been made of $T$. pseudospiralis findings in avian species. The birds that have been documented as naturally infected and positive for $T$. pseudospiralis all fit the profile of being carnivorous, omnivorous, scavenging, or carrion-feeding. In 1980, two omnivorous rooks (Corvus frugilegus) were documented as being naturally infected for the first time (Shaikenov, 1980). A black vulture (Coragyps atratus) was documented as the first host of T. pseudospiralis in North America, found in 1995 in the state of Alabama (Lindsay et al., 1995). According to mentioned authors, three other cases were previously reported in North America; one in a great horned owl (Bubo virginianus) in Iowa, one in a Cooper's hawk (Accipiter cooperi) in California, and one pomarine jaeger (Stercorarius pomariunus) in Alaska. However, these three cases were unverified, making the positive finding of $T$. pseudospiralis in the black vulture the only documented case in birds in North America to date. T. pseudospiralis was also reported by Obendorf and Clarke (1992) in a masked owl (Tyto novaehollandiae) in Tasmania. The wide geographical range of positive findings in birds suggests that T. pseudospiralis is established in its ecological niche worldwide.

When investigating the specific role of carnivorous or omnivorous birds as a primary host of $T$. pseudospiralis, it is important also to consider the natural prey of these animals and how they may interplay in the vast epidemiologi- 
cal picture of this parasite. Therefore, it is recommended to include corvid bird species in future monitoring programs of T. pseudospiralis (Nöckler et al., 2006). Focusing primarily on migratory avian species in a surveillance study may be particularly relevant to detecting positive $T$. pseudospiralis transmission in the European region.

Our study confirmed the participation of birds-of-prey in circulation of Trichinella pseudospiralis in the wildlife of Sweden and also introduced new questions regarding the epidemiological cycle of the parasite. Since the only birds that have been found infected with this Trichinella species in Europe are owls, further study is necessary to determine if there are specific factors that correlate with a higher prevalence of $T$. pseudospiralis in nocturnal owl species than those of diurnal birds of prey and corvids.

\section{Acknowledgements}

The work was supported by the State Agency VEGA No. 1/0702/12 and project "Application Centre for Protection of Humans, Animals and Plants Parasites" (code ITMS: 26220220018), supported by the Research \& Development Operational Programme funded by the ERDF (0.2).

\section{References}

Airas, N., SaAri, S., Mikkonen, T., Virtala, A. M., Pellika, J., OKsanen, A., Isomursu, M., Sukura, A. (2010): Trichinella in the North. Acta Vet. Scand., 52 (Suppl 1): S8. DOI: 10.1186/1751-0147-52-S1-S8

BIRDGUIDES Ltd. (2013) London, Western Palearctic List [Online], Available: http://www.birdguides.com. Accessed 1 October 2013

Calero, R., Martinéz, F., Hernadéz, S. (1978): Parasitacion de Buteo Buteo (Aves: Accipitridae) por Trichinella sp. en el Parque Zoologico de Jerez de la Fronterera. Rev. Iber. Parasitol., 38: 135 - 138 (In Spanish)

Gamble, H. R., Bessonov, A. S., Cuperlovic, K., Gajadhar, A. A., VAn Knappen, F., Nöckler, K., SCHENONE, H., ZHU, X. (2000): International Commission on Trichinellosis: recommendations on methods for the control of Trichinella in domestic and wil animals intended for human consumption. Vet. Parasitol., 93: 393 - 408. DOI: $10.1016 / \mathrm{S} 0304-4017(00) 00354-\mathrm{X}$

GARKAVI, B. L. (1972): Species of Trichinella isolates from wild animals. Veterinarya (Moscow), 10: 90 - 91

Hafner, M. S., Sudman, P. D., Villablanca, F. X., Spradling, T. A., Demaster, J. W., Nadler, S. A. (1994): Disparate rates of molecular evolution in cospeciating hosts and parasites. Science 265: 1087 - 1090. DOI: 10.1126/science.8066445

HURNÍKOVÁ, Z., DUBINSKÝ, P. (2009): Long-term survey on Trichinella prevalence in wildlife of Slovakia. Vet. Parasitol., 159: 276 - 280. DOI: 10.1016/j.vetpar.2008.10.056 HurníkovÁ, Z., Š́nÁBEl, V., PoZIO, E., REITEROVÁ, K., HrČKOVÁ, G., HAlÁsOVÁ, D., DubinskÝ, P. (2005): First record of Trichinella pseudospiralis in the Slovak Republic found in domestic focus. Vet. Parasitol., 128: $91-98$. DOI: 10.1016/j.vetpar.2004.11.013

JAKSIC, F. M. (1982): Inadequacy of activity time as a niche difference: The case of diurnal and nocturnal raptors. Oecologia, 52:171 - 175

KAPEL, C. M. O., GAMBLE, H. R. (2000): Infectivity, persistence, and antibody response to domestic and sylvatic Trichinella spp. in experimentally infected pigs. Int. J. Parasitol., 30: 215 - 221. DOI: 10.1016/S0020-7519(99)00202-7 Kinsella, J. M., Foster, G. W., Forrester, D. J. (2001): Parasitic helminths of five species of owls from Florida, USA. Comp. Parasitol., 68:130 - 134

LA Rosa, G., Marucci, G., Zarlenga, D. S., Pozio, E. (2001): Trichinella pseudospiralis populations of the Palearctic region and their relationship with populations of the Nearctic and Australian regions. Int. J. Parasitol., 31: 297 - 305. DOI: 10.1016/S0020-7519(01)00110-2

Lindsay. D. S., Zarlenga, D. S., GAmble, H. R., AlYAman, F., SMith, P. C., BlagBurn, B. L. (1995): Isolation and characterisation of Trichinella pseudospiralis Garkavi, 1972 from Black Vulture (Coragyps atratus). J. Parasitol., 81: 920 - 923

LUNDBERG, A. (1980): Why are the Ural owl Strix uralensis and the Tawny owl $S$. aluco parapatric in Scandinavia? Ornis Scandinavica., 11: $116-120$

Malakauskas, A., Paulauskas, A., Jarvis, T., KeIDANS, P., EDDI, C., KAPEL, C. M. O. (2007): Molecular epidemiology of Trichinella spp. in three Baltic countries: Lithuania, Latvia, and Estonia. Parasitol. Res., 100: 687 693. DOI: 10.1007/s00436-006-0320-y

Nagano, I., Wu, Z., Matsuo, A., Pozio, E., TAKahashi, Y. (1999): Identification of Trichinella isolates by polymerase chain reaction-restriction fragment lenght polymorphism of the mitochondrial cytochrome c-oxidase subunit I gene. Int. J. Parasitol., 29: 1113 - 1120. DOI: 10.1016/S0020-7519(99)00060-0

NöcKleR, K., Reckinger, S., PozIO, E. (2006): Trichinella spiralis and Trichinella pseudospiralis mixed infection in a wild boar (Sus scrofa) of Germany. Vet. Parasitol., 137: 364 - 368. DOI: 10.1016/j.vetpar.2006.01.031

OBEndorf, D. L., ClARK, K. P. (1992): Trichinella pseudospiralis infections in free-living Tasmanian birds. $J$. Helminthol. Soc.Wash., 59: 144-147

Oivanen, L., Kapel, C. M. O., Pozio, E., La Rosa, G., MikKonen, T., SuKurA, A. (2002): Associations between Trichinella species and host species in Finland. J. Parasitol., 88: 84 - 88. DOI: 10.1645/0022-3395(2002)088[0084: ABTSAH]2.0.CO;2

Oivanen, L., NÄrEAHO, A., Jokela, S., RiKula, U., GAMBLE, R., SUKURA, A. (2005): The prevalence of Trichinella infection in domestic dogs in Finland. Vet. Parasitol., 132: 125 - 129. DOI: 10.1016/j.vetpar.2005.05.040

Oivanen, L., OKSAnEN, A. (2009): Synanthropic Trichinella infection in Finland. Vet. Parasitol., 159: 281 - 284. DOI: $10.1016 /$ j.vetpar.2008.10.057

POZIO, E. (2005): The broad spectrum of Trichinella hosts: From cold- to warm-blooded animals. Vet. Parasitol., 132: 3 - 11. DOI: 10.1016/j.vetpar.2005.05.024 
POZIO, E. (2009): World distribution of Trichinella spp. infections in animals and humans. Vet. Parasitol., 149: 3 21. DOI: $10.1016 /$ j.vetpar.2007.07.002

PozIO, E., LA RosA, G. (2003): PCR-derived methods for the identification of Trichinella parasites from animal and human samples. Methods in Molecular Biology 216: 299 309. DOI: 10.1385/1-59259-344-5:299

PozIO, E., MurRelL, K.D. (2006): Systematics and epidemiology of Trichinella. Adv. Parasitol., 63: 367 - 439. DOI: 10.1016/S0065-308X(06)63005-4

Pozio, E., Goffredo, M., Fico, R., LA Rosa, G. (1999): Trichinella pseudospiralis in sedentary night-birds of prey from Central Italy. J. Parasitol., 85: 759 - 761

PozIO, E., Christensson, D., Sten, M. (2004): Trichinella pseudospiralis foci in Sweden. Vet. Parasitol. 125: 335 342. DOI: 10.1016/j.vetpar.2004.07.020

Pozio, E., ZarlengA, D. S. (2013) New pieces of the Trichinella puzzle. Int. J. Parasitol. 43: 983 - 997. DOI: dx.doi.org/10.1016/j.ijpara.2013.05.010
Santoro, M., Kinsella, J. M., Galiero, G., Degli Uberti, B., Aznar, F. J. (2012): Helminth community structure in birds of prey (Accipitriformes and Falconiformes) in southern Italy. J. Parasitol., 98: 22 - 29. DOI: 10.1645/GE-2924.1

SHAIKENOV, B. (1980): Spontaneous infection of birds with Trichinella pseudospiralis Garkavi, 1972. Folia Parasitol., 27: 27 - 30

ZARlengA, D. S., DAME, J. B. (1992): The identification and characterisation of a break within the large subunit ribosomal RNA of Trichinellaspiralis:comparison of gap sequences within the genus. Mol. Biochem. Parasitol., 51: $281-290$

Wu, Z., ŠnÁBEl, V., Pozio, E., HuRníKOVÁ, Z., NAREAHO, A., NAGANO, I., TAKAHASHI, Y. (2007): Genetic relationships among Trichinella pseudospiralis isolates from Australian, Nearctic, and Palearctic regions. Parasitol. Res., 101: 1567 - 1573. DOI: 10.1007/s00436-007-0677-6 